UDC 614/5:644.36

DOI: 10.21668/health.risk/2020.1.18.eng

\title{
IRRATIONAL LIGHTING AS A HEALTH RISK OCCURRING IN THE ARCTIC
}

\author{
V.A. Kaptsov ${ }^{1}$, V.N. Deinego ${ }^{2}$ \\ ${ }^{1}$ All-Russian Research Institute of Railway Hygiene, Bldg. 1, 1 Pakgauznoe shosse, Moscow, 125438, \\ Russian Federation \\ ${ }^{2}$ Scientific and production commercial company "ELTAN LTD”, 2 Zavodskoy Prospekt, Fryazino, 141190, \\ Russian Federation
}

We assessed health risks for operators who had to live in mobile houses in the Arctic regions. Inadequate lighting is a most significant factor related to housing conditions that can cause various pathologies resulting in decreasing working capacity. We revised data on impacts exerted by luminous and LED lighting on operators and it allowed us to determine reasons for "aftereffects" produced by LED lighting regarding an increase in latency in No. 95 pattern electroretinogram (PERG); this latency characterizes a situation with ganglionic cells in the visual analyzer. We put forward a hypothesis that lower "inhibition" efficiency was caused by absorption of blue light within 380-450 nanometers range, and an increase in PERG P50 amplitude was caused by an additional increase in $\mathrm{Na}^{+}, \mathrm{Ca}^{+}$ions flows when ChR2 protein absorbed excessive $470 \mathrm{~nm}$ blue light against a blue light dose in a luminous lamp spectrum.

We showed that there were practically no changes in operators' health after they had been exposed to dynamic LED lighting; however, all the participants in the experiment had a W-like splitting in P100 peak in visually induced cortical potentials as a response to stimuli with different angle sizes. When ganglionic cells are exposed to blue lighting, interaction between their degrading mitochondria and astrocytes becomes very important. LED lighting results in damage to mitochondria in ganglionic cells. Mitochondria are moved to the optic nerve head to be utilized where they are absorbed by astrocytes and eliminated with their lysosome. Should a speed of degrading mitochondria inflow exceed a speed at which they are utilized, it will cause mechanic strains in fibers of the optic nerve head due to "mitochondria jam"; this, in its turn, can lead to long-term disorders in the optic nerve head and glaucoma occurrence.

We formulated recommendations for the State Standard 23274-84 "Mobile houses. Electrical appliances. Overall technical conditions" and advised applying semi-conductor white light sources in them as they had a biologically adequate irradiation spectrum.

Key words: mobile houses, LED lighting, blue light, optic nerve, mitochondrion, astrocyte, glaucoma, biologically adequate irradiation spectrum.

The Arctic zone is naturally essential for the Russian Federation; development of the region is truly vital bearing in mind not only future prospects but also outstanding economic tasks the country is to solve at present. The Arctic zone is an essential border outpost where our northern borders are protected. Today, there is a base built by the RF Defense Ministry on Zemlya Aleksandry, an island belonging to the Zemlya Frantsa-Iosifa archipelago. The base is called «The Arctic trefoil». Overall, the Defense Ministry is planning to build 6 military settlements, 13 airfields, a land aviation range, and 10 technical facilities for radar stations and targeting points in the Arctic zone. These bases are planned to provide placement for several thousand military personnel; these people will have to spend most part of a year in the region during the polar night and live with artificial light only with its spectrum not being similar to that of sunlight.

Poor lighting quality is known to be able to cause a shift in a circadian phase, especially when it is combined with sleep disorders at night. Poor lighting during a day can also cause somnolence. A human body requires both periods with bright lighting and periods of darkness during a day in order to maintain an optimal daily rhythm. Should this rhythm be disharmonized, it can result in both physiological changes and health disorders and, consequently, lower working capacity and intellectual abilities.

(C) Kaptsov V.A., Deinego V.N., 2020

Valerii A. Kaptsov - Doctor of Medical Sciences, The Corresponding Member of the RAS, Head of the Occupational Hygiene Department (e-mail: kapcovva39@mail.ru; tel.: +7 (499) 15-33-628; ORCID: http://orcid.org/0000-0002-3130-2592).

Vitalii N. Deinego - Senior researcher (e-mail: vn-led@bk.ru; tel.: +7 (916) 530-68-82). 
Some say, that Diogenes, an ancient Greek philosopher, was able to develop his talents due to living in a tub. Dozen thousand people working in the Arctic zone have been living in comfortable and warm metallic «tubs», an all-metal cylinder-like unified block; sometimes they felt themselves being «contemporary Diogeneses...» [1].

Life-giving light makes a tub a true home for a person and exerts favorable influence on his or her health and creative abilities.

An idea to live in well-lit cylinder-like houses turned out to be quite feasible and practical. It found its implementation in the arctic zones, space, and sea depths. A cylinder-like shape provides high security during transportation in areas without good roads, minimal quantities of metal required to make it, minimal labor and other costs as well.

TSUB-2M housing module has become widely spread as it is equipped with all necessary communal utilities and can provide accommodation for 4 people who work on shifts in the arctic regions and other remote areas. TSUB-2M houses are also used in the army where they serve as accommodation for military personnel in unpopulated areas. All-metal complete unified blocks for military personnel have an advantage related to their readiness to provide accommodation immediately as they are equipped with all necessary appliances, such as folding sleeping berths, tables, and sanitary units.

All the above mentioned peculiarities allowed providing maximum possible comfort for people living in TSUB-2M blocks in northern regions with filament lamps being their only light source.

Figure 1 shows a layout of a modern mobile building that can provide accommodation for 8 people; there are two basic models, «CABA A8» 8x2.4 or «CABA A8»8x2.8 [2].

To light TSUB blocks, different lighting sources were applied, starting from filament lamps and on to luminous and energy-saving lamps; they were then replaced by LED lighting. In 2018 a state standard GOST 23274-84 ${ }^{1}$ was approved; its authors made provisions for used of LED lighting. Item 3.4.4 in the said document fixes that «to provide electrical lighting inside a building, one, as a rule, should use lighting appliances with luminous and LED lighting sources. It is also permissible to use filament lamps in case it is impossible to use the above mentioned lighting sources». But it raises an issue whether it is truly advisable and permissible to apply too bright LED lighting sources in rooms with low ceilings as per GOST 22853-86 ; according to the said document, dimensions of container housing should correspond to values given in Table 1 .

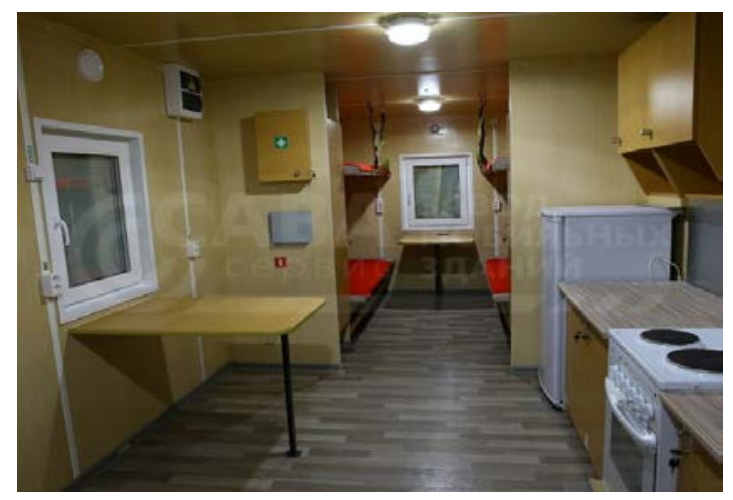

Figure 1. A possible TCUB layout for 8 people equipped with two-tier sleeping berths and energy-saving lamps

It is very important to estimate whether luminous and LED tubes are photobiologically safe in case of mobile houses with low ceilings (2,200 $\mathrm{mm}$ height); they should correspond to IEC $62471: 2013^{3}$ standard. When a room height is equal to $2,200 \mathrm{~mm}$, lamps are too close to human eyes. And when photo-safety is estimated, it is very important to assess dependence between basic luminance of a lighting source and a distance between it and human eyes. Such dependences were obtained for a $200 \mathrm{~mm}$ distance and further on to $1,000 \mathrm{~mm}$ distance in works by F. Leccese et al. [3]; the results are given on Figures 2 and 3 .

\footnotetext{
${ }^{1}$ GOST 23274-84 Mobile buildings (inventory buildings). Electrical units. Overall technical conditions. GOSTs database. Available at: https://allgosts.ru/91/140/gost 23274-84 (12.04.2019) (in Russian).

${ }^{2}$ GOST 22853-86. Mobile buildings (inventory buildings). Overall technical conditions. KODEKS: an electronic fund for legal and reference documentation. Available at: http://docs.cntd.ru/document/gost-22853-86 (12.04.2019) (in Russian).

${ }^{3}$ GOST IEC 62471-2013. Photobiological safety of lamps and lamp systems. Normaks. The system of standards. Available at: http://www.normacs.ru/Doclist/doc/12080.html (12.04.2019) (in Russian).
} 
Table 1

\begin{tabular}{|c|c|c|c|c|c|c|}
\hline \multirow{2}{*}{ A building } & \multirow{2}{*}{ Width } & \multicolumn{4}{|c|}{ Length } & \multirow{2}{*}{ Height* } \\
\hline & & 3,000 & 6,000 & 9,000 & 12,000 & \\
\hline $\begin{array}{l}\text { Towed** with non-detachable } \\
\text { running gear } \\
\text { Transported*** and towed with } \\
\text { detachable running gear }\end{array}$ & $\begin{array}{l}2,500 \\
3,000 \\
3,000\end{array}$ & $\begin{array}{l}+ \\
- \\
+\end{array}$ & $\begin{array}{l}+ \\
+ \\
+\end{array}$ & $\begin{array}{l}+ \\
+ \\
+\end{array}$ & $\begin{array}{l}- \\
+ \\
+\end{array}$ & $\begin{array}{c}\text { Not less than } 2,200 \\
\text { The same } 2,400\end{array}$ \\
\hline
\end{tabular}

Note:

* means height of a room inside a block-container is a distance taken directly from the floor to the ceiling. Should a ceiling be not rectilinear, height is taken as per an average value between the maximum and the minimum one;

** towed buildings are those equipped with their own non-detachable or detachable running gear;

$* * *$ transported building are those that are not equipped with a running gear (block-containers).
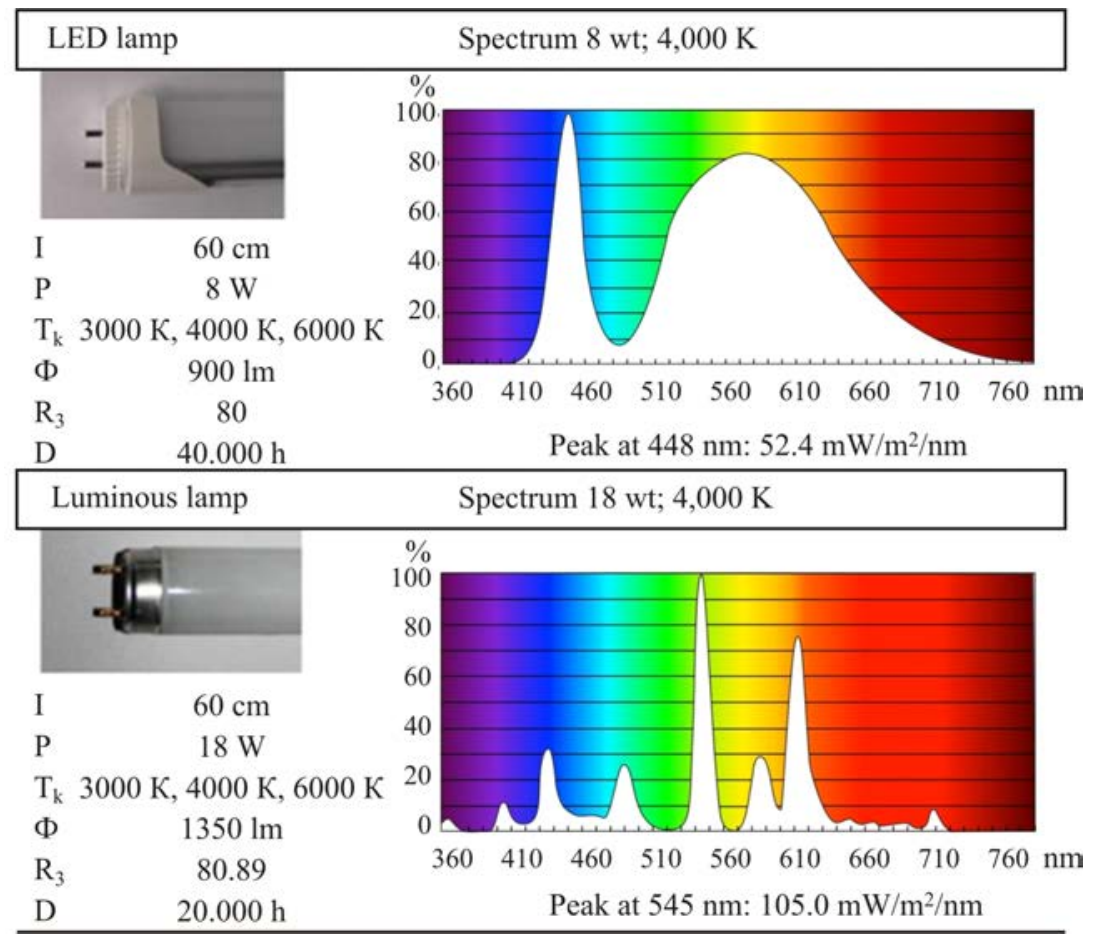

Figure 2. Overall features of a Led Tube lamp and a luminous lamp

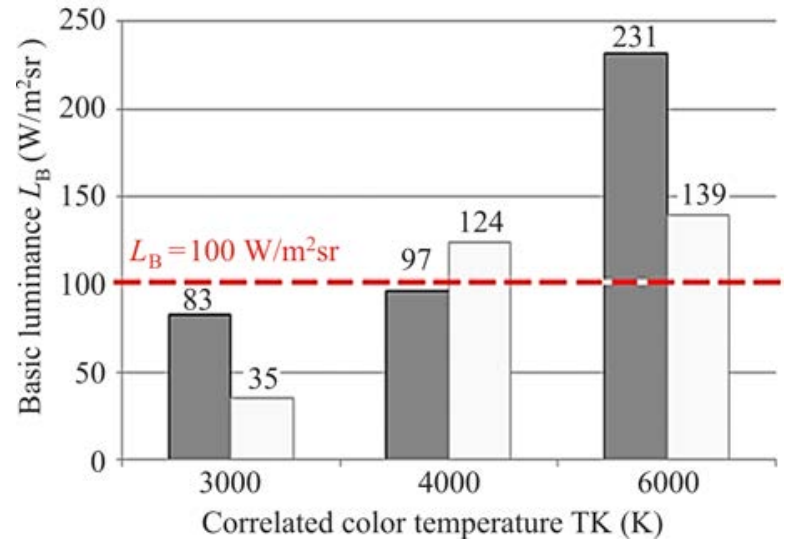

Figure 3. Basic luminance $\mathrm{L}_{\mathrm{B}}$ within blue light range: a comparison between LED (dark grey) and luminous lamps (light grey) with different color temperatures at a distance equal to 0.20 meters

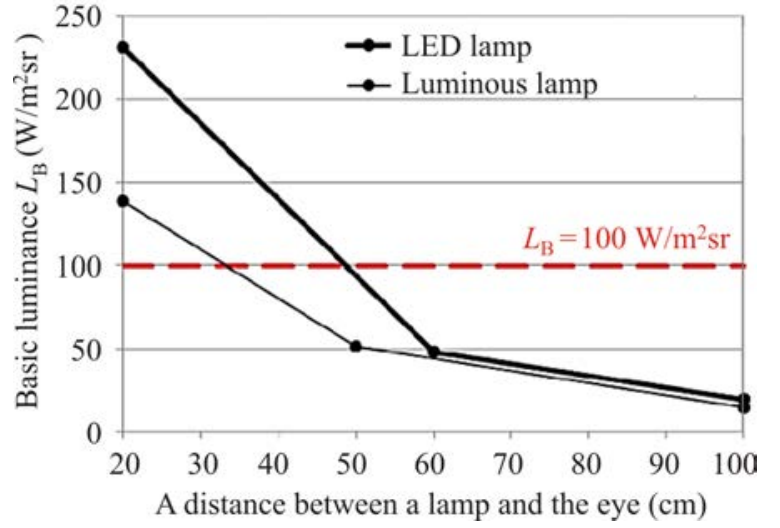

Figure 4. Dependence between basic luminance $\mathrm{L}_{\mathrm{B}}$ of LED tubes and luminous lamps with color temperature $6,000 \mathrm{~K}$ and a distance to the eye [4] 
Figure 4 shows dependence between weighted luminance $\mathbf{L}_{\mathbf{B}}$ of blue light and a distance between a lighting source and the eye.

When a person's height is $180-190 \mathrm{~cm}$ and a ceiling is $210-220 \mathrm{~cm}(2,100-2,200 \mathrm{~mm})$, a minimal permissible distance between the eyes and a LED lamp that is photobiologically safe should be not less than $50 \mathrm{~cm}$. Such TSUB dimensions are comparable to dwelling units at space stations and cabins aboard a ship. L.V. Bazyleva et al. [5] and V.N. Bolekhan et al. [6] state that working out optimal luminance regimes and giving scientific grounds for a possibility of their long-term use in closed objects is a vital practical task not only for the space brunch but also for other spheres of human activities.

Nowadays it is well known that irrational lighting is a most significant factor related to dwelling as it can lead to development of various pathologies accompanied with reduced working capacities ${ }^{4}$.

A blue component (440-460 nm) has the greatest photochemical activity regarding the retinal pigment epithelium. This component prevails in irradiation spectra of modern white LEDs; therefore, many researchers consider LED lamps being potentially hazardous [7]. Overwhelming majority of literature data indicating that LED lighting is photochemically dangerous have been obtained via experiments on animals.

Thus, experiments performed on Japanese quails (Coturnix japonica) revealed that exposure to light from blue LEDs resulted in changes in the choroid as well as photo-induced changes in sub-cellular structures of the retinal pigment epithelium. Those experiments also showed that moderate blue LED lighting (440-460 nm) led to 1.5 times greater loads on the retina metabolism in young animals (against filament lamps); those loads resulted in accelerated ageing of the retina and reduced functional activity of the blood-retinal barrier structures [8].

Results of those experiments confirm a hypothesis that a blue part in the spectrum has more apparent ability to do photochemical damage to the retina than yellow-green and red ones.

However, some foreign and Russian experts [8] believe that results obtained via experiments on animals can't be directly extrapolated on people due to apparent morphofucntional differences of their visual analyzers as well as due to laboratory conditions not corresponding to the natural lighting environment people live in.

There have been few experiments involving human participants and they mostly focused on examining melatonin levels during nighttime. The administration of the RF Defense Ministry Central Research Institute were the first to raise an issue related to obligatory certification of LED lighting sources as per medical standards. But it turned out to be impossible to fulfill such a task in 2007 at the expense of the RF Defense Ministry. In 2008 the US Department of Defense set a task to perform a research work entitled SB082-055 «A Spectrally Dynamic Berth Light for Active Circadian Cycle Management» [9]. The costs on this research amounted to $\$ 98,990.00$. The research clearly indicated that working capacities of military personnel serving on a US Navy ship changed considerably under shortterm exposure to blue part in the light spectrum $[10,11]$.

LED lighting sources used on US Navy ships were developed by Energy Focus Company that signed a governmental contract worth $\$ 1,600,000,000.00$. Roger Buelow, the leading researcher at the company, noted that «The repeated DARPA research revealed how a daily rhythm developed under influence exerted by improved lighting provided for the Navy. Those lighting sources regulated their spectrum during a day in order to improve sleep and performance and it is especially important regarding military personnel who are to be ready to operate round the clock» [12].

A thesis for the Candidate of Medical Sciences by A.E. Smoleevskiii ${ }^{4}$ is one of the latest works focusing on impacts exerted by

\footnotetext{
${ }^{4}$ A.E Smoleevskii. Mental performance of an operator working under LED lighting with different spectral and energetic properties: a thesis for Candidate of Medical Sciences degree. Moscow, GNTS RF-IBMP Publ., 2018, 133 p. (in Russian).
} 
LEDs on mental performance of an operator that turned out to be quite interesting for us.

The research was performed in the RF State Scientific Center - RAS Institute for Medical and Biological Issues in 2014-2015; it was a part of a long-term complex experimental research program entitled «Tests of LEDs for pressurized chambers that are to be used in space crafts and assessment of psychophysiological effects produced by such use»». The research was accomplished on samplings made up of healthy male volunteers; there were two stages in it involving permanent and dynamic lighting during 12 days.

Background parameters of mental performance and psycho-emotional state were estimated under luminous lighting with its colority being equal to $4,000 \mathrm{~K}$ («neutral white» light). Lamps were located in a chamber with a limited volume in such a way that they could create lighting levels corresponding to the existing standards ${ }^{5}$ and were comparable to lighting levels equal to 200 luxes created by experimental LED lamps. After-effects: produced by LED light were also assessed under luminous lighting.

The first stage involved assessing psychophysiological effects produced by permanent LED lighting created by board lighting sources CCD301, CCD305, and CCD307. CCD301 lighting sources were installed in toilets and passages; CCD305 and CCD307 lighting sources, in dwelling and medical units. Correlated color temperature (CCT) of the lighting system amounted to $4,000 \mathrm{~K}$, and luminance was equal to 200 luxes. Hence operational spectral and energetic properties of CCD311 lighting sources changed within a wide range, mental performance of operators was assessed at two CCT values, 4,000-5,000K and $8,000 \pm 800 \mathrm{~K}^{4}$.

Unfortunately, the thesis doesn't contain any data on spectral and energetic properties of CCD301, CCD305, CCD307, and CCD311 LED lamps; there are only data on LEDs applied in lighting sources manufactured by
CREE and Seoul Semiconductor companies. To hygienically assess spectral properties of applied lighting sources, we have to rely on spectra of LEDs produced by CREE (Figure 5).

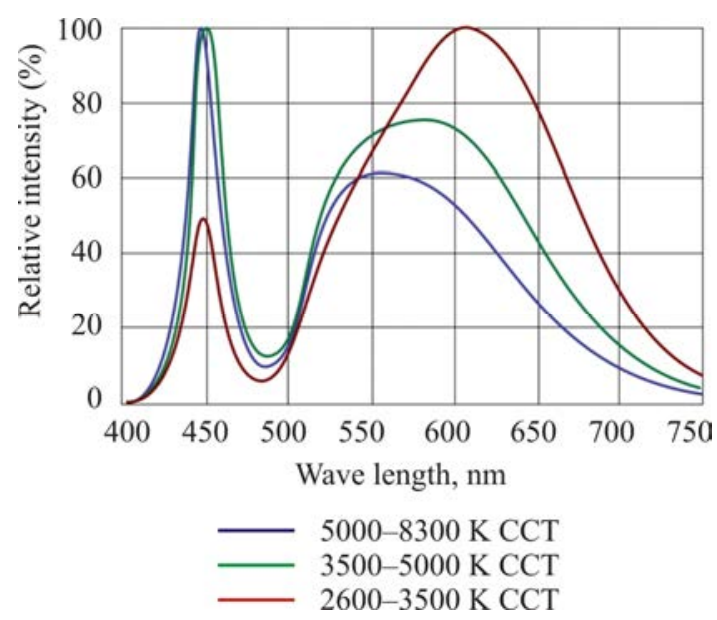

Figure 5. Spectra of LEDs produced by CREE

We can assume that spectra of applied LED lamps had little difference from the LED lamps produced by the said companies provided that «NII Mikropriborov» Scientific Center LLC that produced those LED lamps didn't apply any specific procedures aimed at adjusting LED spectra.

A spectrum of a LED lamp produced by CREE Company and shown in Figure 5 allows assuming that:

- this spectrum has an increased dose of blue light against hygienically safe sunlight under the same luminance;

- the maximum in the spectrum is at 450 $\mathrm{nm}$ blue light and it exerts negative impacts on the retina (on synapses in the dendritic field of ganglionic cells in the retina optic channel);

- blue light that produces its effects on ganglionic cells in the eye is equal to $60 \%$ of the maximum blue light value that is $450 \mathrm{~nm}$; so, effects produced on the hormonal system (melatonin and hydrocortisone concentrations) and comfortable sleep are not so apparent;

- bearing the eye physiology in mind, we should remember that it is ganglionic cells and their dendritic field that are the first to perceive blue light. Excessive blue light dose ex-

\footnotetext{
${ }^{5}$ GOST R 50804-95. The dwelling environment of an astronaut in a manned space craft. Overall medical and technical requirementsю KODEKS: an electronic fund for legal and reference documentation. Available at: http://docs. cntd.ru/document/gost-r-50804-95 (12.04.2019) (in Russian).
} 
erts its impacts on performance of ganglionic cells that perceive signals from other photosensitive retina cells reacting to light stimuli;

- there is a clear dip at $480 \mathrm{~nm}$ in the spectrum. Photon flow of $480 \mathrm{~nm}$ light-blue light is responsible for managing the pupil diameter and holding it closed. A dilated pupil exposed to LED light can't limit light flow with excessive blue light dose.

Authors of the research work [13] revealed dependence between the pupil diameter and luminance for LEDs with their spectrum given in Figure 5 (Figure 6).

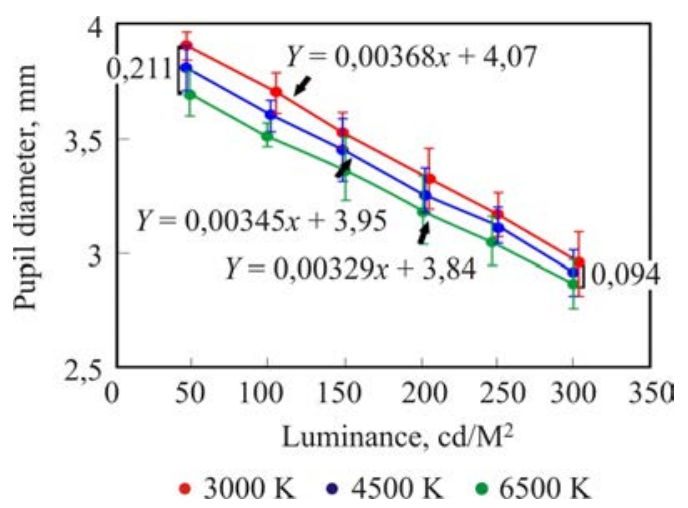

Figure 6. Dependence between the pupil diameter and luminance [13]

When overall illumination is equal to 200 luxes, luminance from a white sheet of paper is equal to less than $100 \mathrm{~cd} / \mathrm{m}^{2}$. It means that the pupil diameter will be greater than $3.5 \mathrm{~mm}$. When the eye is exposed to such illumination and irradiation spectra, we can assume there is an elevated risk of «after-effects» in accommodative apparatus functioning, stochastic effects in retinal cells functioning, and changes in mental state of a person caused by excessive doses of blue light (from $4,500 \mathrm{~K}$ to $8,000 \pm 800 \mathrm{~K})$.

Table 2 contains aggregated data on mental state of operators exposed to LED lighting with different lighting regimes. The examination was performed as per «Profile of mood» procedure, a Russian analogue of «Profile of mood states» questionnaire which is widely used in isolation and space-related experiments ${ }^{4}$.
The given data clearly indicate that LED lighting exerts significant influence on mental state of some operators and it can result in negative consequences in small teams working in closed spaces. It is truly important to understand significance of these results for keeping a favorable working atmosphere among people fulfilling challenging tasks under grave conditions in the arctic zones or in sealed cabins (a space craft).

As per results obtained via completed examinations, the author pointed out that there was a decrease in certain functional parameters:

- relative accommodation reserves (by $14.3 \%$ as per median);

- aggregated field of vision border between blue and green color (by 6.3\% and 9.1\% as per median accordingly) without any subjective symptoms occurrence. However, there was a decrease in critical light flicker frequency in $25 \%$ operators after exposure to LED lighting (Operator No. 3 by 4 arbitrary units, up to 42/42 after $38 / 38$, Operator No. 6 by 3 arbitrary units, up to $45 / 45$ after $42 / 42)^{4}$.

It is interesting to examine a patternERG (PERG) that characterizes functions of the direct sight (P50) and ganglionic cells in the retina (N95) [14], Pattern-electroretinogram (PERG) is the most sensitive test to determine ganglionic cells function. When a person suffers from primary open-angle glaucoma (POAG), there is primary damage to ganglionic cells [15]. The work [15] contains data on (P50) and (N95) values in patients with primary glaucoma. The research was accomplished in a consulting polyclinic of the Republic Clinical eye Hospital in Kazan and involved examining 21 patients suffering from POAG. Aggregated results of the first measurements are given in Table 3.

A form of PERG signal response was standardized by ISCTV (International Society for Clinical Electrophysiology of Vision) ${ }^{6}$. A standard response is given In Figure 7 that shows $\mathrm{P}(50)$ and N95 levels characteristic for primary glaucoma.

\footnotetext{
${ }^{6}$ Standards, Guidelines and Extended Protocols. International Society for Clinical Electrophysiology of Vision. Available at: https://iscev.wildapricot.org/standards/ (12.04.2019) (in Russian).
} 
Mental performance of operators working under LED lighting

\begin{tabular}{|c|c|c|}
\hline \multirow{2}{*}{ Parameter scales } & \multicolumn{2}{|c|}{$\begin{array}{l}\text { Number of operators with changes in their mental performance (changes } \\
\text { in parameters fixed in arbitrary units) in comparison with reference groups } \\
\text { (working under luminous lighting) }\end{array}$} \\
\hline & $\begin{array}{l}\text { Mental performance under LED } \\
\text { lighting with permanent spectral } \\
\text { and energetic properties (permanent } \\
\text { LED lighting } 4,000 \mathrm{~K} \text { ) }\end{array}$ & $\begin{array}{l}\text { Profile of moods specific for an operator } \\
\text { under LED lighting with changing spectral } \\
\text { and energetic properties (dynamic LED } \\
\text { lighting, } 4,000-5,000 \mathrm{~K} \text { and } 8,000 \pm 800 \mathrm{~K} \text { ) }\end{array}$ \\
\hline "Anger - hostility" & $\begin{array}{l}\text { Increased by } 3 \text { a.u. in } 2 \text { operators } \\
\text { Decreased by } 2-4 \text { a.u. in } 3 \text { operators } \\
\text { No changes in } 5 \text { operators }\end{array}$ & $\begin{array}{l}\text { Increased by } 10-20 \text { a.u. (by } 2-3 \text { times) } \\
\text { in } 5 \text { operators } \\
\text { Decreased by } 2-3 \text { a.u. in } 2 \text { operators } \\
\text { No changes in } 1 \text { operator }\end{array}$ \\
\hline "Depression - gloom" & $\begin{array}{l}\text { Decreased by } 1-3 \text { a.u. in } 2 \text { operators } \\
\text { Increased by } 1-3 \text { a.u. in } 2 \text { operators } \\
\text { No changes in } 6 \text { operators }\end{array}$ & $\begin{array}{l}\text { Decreased by } 3-6 \text { a.u. in } 2 \text { operators } \\
\text { Increased by } 1-3 \text { a.u. in } 3 \text { operators } \\
\text { No changes in } 3 \text { operators }\end{array}$ \\
\hline "Fatigue - inertia" & $\begin{array}{l}\text { Increased by } 2-9 \text { a.u. in } 4 \text { operators } \\
\text { Decreased by } 1-3 \text { a.u. in } 4 \text { operators } \\
\text { No changes in } 2 \text { operators }\end{array}$ & $\begin{array}{l}\text { Increased by } 2-9 \text { a.u. in } 3 \text { operators } \\
\text { Decreased by } 2-4 \text { a.u. in } 3 \text { operators } \\
\text { No changes in } 2 \text { operators }\end{array}$ \\
\hline "Vivacity - activity" & $\begin{array}{l}\text { Decreased by } 2-8 \text { a.u. in } 6 \text { operators } \\
\text { Increased by } 1-6 \text { a.u. in } 3 \text { operators } \\
\text { No changes in } 1 \text { operator }\end{array}$ & $\begin{array}{l}\text { Decreased by } 2-8 \text { a.u. in } 3 \text { operators } \\
\text { Increased by } 2-5 \text { a.u. in } 2 \text { operators } \\
\text { No changes in } 3 \text { operators }\end{array}$ \\
\hline "Stress - anxiety" & $\begin{array}{l}\text { Increased by } 1-4 \text { a.u. in } 4 \text { operators } \\
\text { Decreased by } 1-7 \text { a.u. in } 4 \text { operators } \\
\text { No changes in } 2 \text { operators }\end{array}$ & $\begin{array}{l}\text { Increased by } 5-12 \text { a.u. in } 4 \text { operators } \\
\text { Decreased by } 1-3 \text { a.u. in } 2 \text { operators } \\
\text { No changes in } 2 \text { operators }\end{array}$ \\
\hline "Confusion - uncertainty & $\begin{array}{l}\text { Increased by } 3 \text { a.u. in } 1 \text { operator } \\
\text { Decreased by } 1-2 \text { a.u. in } 5 \text { operators } \\
\text { No changes in } 4 \text { operators }\end{array}$ & $\begin{array}{l}\text { Increased by } 1-10 \text { a.u. in } 4 \text { operators } \\
\text { Decreased by } 1-2 \text { a.u. in } 3 \text { operators } \\
\text { No changes in } 1 \text { operator }\end{array}$ \\
\hline $\begin{array}{l}\text { Integral mood parameters - } \\
\text { "Overall changes in mood" }\end{array}$ & $\begin{array}{l}\text { Increased by } 5-25 \% \text { in } 5 \text { operators } \\
\text { Decreased by } 15-20 \% \text { in } 4 \text { operators } \\
\text { No changes in } 1 \text { operator }\end{array}$ & $\begin{array}{l}\text { Increased by } 30-230 \% \text { in } 5 \text { operators } \\
\text { Decreased by } 5-30 \% \text { in } 3 \text { operators } \\
\text { No operators without changes }\end{array}$ \\
\hline
\end{tabular}

Table 3

PERG parameters in patients with primary glaucoma

\begin{tabular}{|l|c|}
\hline \multicolumn{1}{|c|}{ PERG parameters } & Prior to treatment \\
\hline $\mathrm{P}(50)$ Latency $\mathrm{ms}$ & $74^{+} .3 .3$ \\
\hline $\mathrm{N}(95)$ Latency $\mathrm{ms}$ & $118^{+} .4 .2$ \\
\hline
\end{tabular}

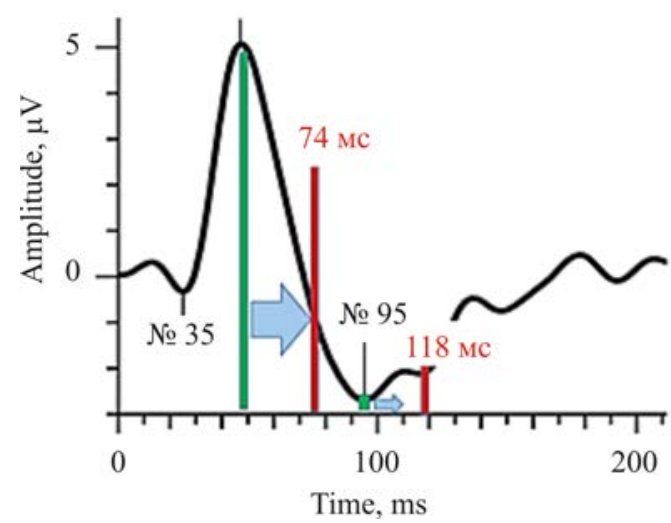

Figure 7. A standard response with given $\mathrm{P}(50)$ and N95 values characteristic for primary glaucoma $[16,17]$
V.V. Egorov et al. give normal PERG responses in their work [18] (Figure 8).

This response pattern contains two basic components, a positive one approximately at 50-55 $\mathrm{ms}$ (P50) and negative one approximately at 85-90 ms (N95).

Latency parameter is the most informative in our case. It should be noted that latency reserve in a standard PERG N95 parameter is rather small and is equal to $23 \mathrm{~ms}$; it is quite comparable to that of $\mathrm{P}(50)$ parameter which is equal to $24 \mathrm{~ms}$. These reserve can be spent over years in patients' life.

Table 4 contains aggregated results obtained via PRG examination from the research work [18].

The given data show that latency time grew from $2 \mathrm{~ms}$ to $19-28 \mathrm{~ms}$ as per N95 parameters under LED lighting with color temperature being higher than $4,000 \mathrm{~K}$ but lower 


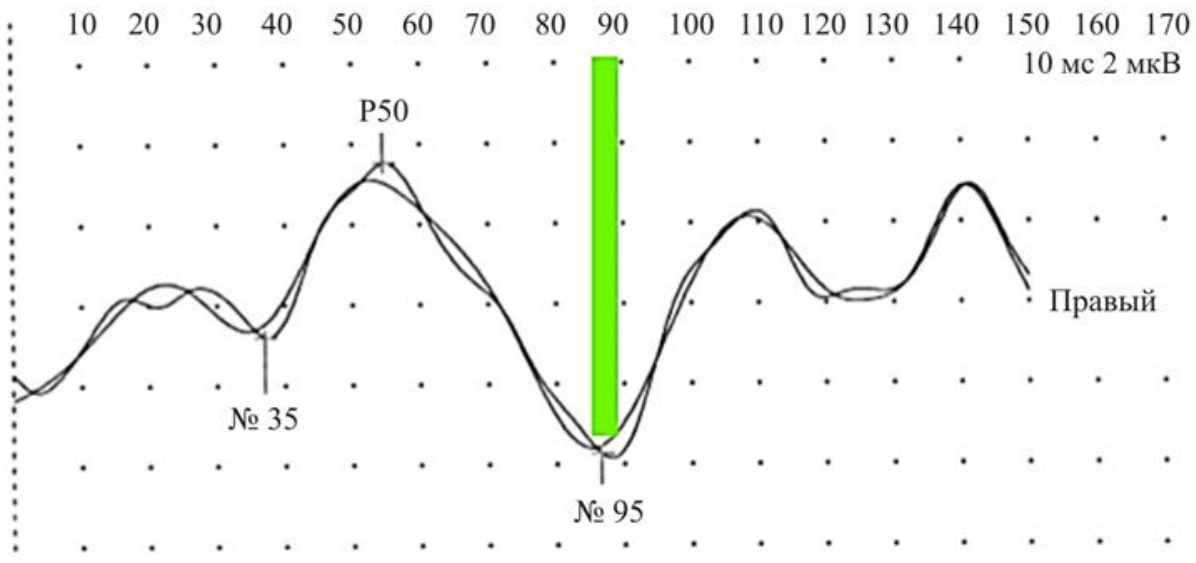

Figure 8. Standard ERG pattern [18]

Table 4

Aggregated results of PERG examination

\begin{tabular}{|c|c|c|c|c|c|c|}
\hline \multirow{2}{*}{ Operator } & \multirow{2}{*}{ Eye } & \multirow{2}{*}{$\begin{array}{l}\text { Exposure } \\
\text { stage }\end{array}$} & \multicolumn{2}{|c|}{$\begin{array}{c}\text { Cells sizes } \\
\mathbf{0 . 8}^{\mathbf{0}}\end{array}$} & \multicolumn{2}{|c|}{$\begin{array}{c}\text { Cells sizes } \\
\mathbf{0 . 3}^{\mathbf{0}}\end{array}$} \\
\hline & & & $\begin{array}{c}\text { P50 } \\
\text { T(ms) }\end{array}$ & $\begin{array}{c}\text { №95 } \\
\text { T(ms) }\end{array}$ & $\begin{array}{c}\text { P50 } \\
\text { T(ms) }\end{array}$ & $\begin{array}{c}\text { №95 } \\
\text { T(ms) }\end{array}$ \\
\hline \multirow{4}{*}{1} & \multirow{2}{*}{ right eye } & before & 48.3 & 81.7 & 55.7 & 98.3 \\
\hline & & after & 53.9 & 101.4 & 55.7 & 105.7 \\
\hline & \multirow{2}{*}{ left eye } & before & 52.8 & 96.5 & 50.4 & 95.5 \\
\hline & & after & 52.1 & 108.1 & 55.3 & 105.3 \\
\hline \multirow{4}{*}{2} & \multirow{2}{*}{ right eye } & before & 50.4 & 88.4 & 50 & 92.3 \\
\hline & & after & 50.4 & 108.1 & 58.1 & 111.8 \\
\hline & \multirow{2}{*}{ left eye } & before & 51.1 & 87.7 & 54.6 & 92.6 \\
\hline & & after & 50.7 & 108.1 & 56 & 98.3 \\
\hline \multirow{4}{*}{3} & \multirow{2}{*}{ right eye } & before & 53.9 & 108.5 & 54.2 & 97.9 \\
\hline & & after & 57.1 & 98.3 & 50 & 89.5 \\
\hline & \multirow{2}{*}{ left eye } & before & 52.5 & 89.8 & 54.6 & 96.9 \\
\hline & & after & 55.3 & 117.3 & 60 & 98.3 \\
\hline \multirow{4}{*}{4} & \multirow{2}{*}{ right eye } & before & 53.2 & 92.6 & 53.5 & 96.9 \\
\hline & & after & 52.5 & 108.8 & 53.9 & 98.3 \\
\hline & \multirow{2}{*}{ left eye } & before & 49.3 & 92.6 & 53.5 & 97.6 \\
\hline & & after & 52.1 & 104.6 & 51.4 & 87.7 \\
\hline
\end{tabular}

than $8,800 \mathrm{~K}$. This «after-effect» persisted in measurements performed by experts from the Clinical Eyesight Physiology Department at Helmholtz' Moscow Scientific Research Institute for Eye Diseases of the RF Public Healthcare Ministry ${ }^{4}$.

Examining biological effects produced on a person by light remains a vital issue in lighting hygiene. Experiments performed at cellular, biological, and psychophysiological levels allowed proving that artificial and natural light with the same intensity were still not biologically adequate; this inadequacy per- sisted when illuminance from artificial sources grew [19].

This fact indicates that it is necessary to accomplish more profound research on studying stable functions of hydrogen, sodium, and chlorine ATPase in a scheme of sodiumcalcium-chlorine transport within cells (their dendrites and mitochondria) [20] under exposure to excessive dose of $450 \mathrm{~nm}$ blue light.

A change in ions concentration leads to changes in water flows from cellular membranes and changes in their $\mathrm{pH}$ [21]. Light exerts substantial impacts on transfer of the said 
ions as it influences proteins in relevant receptors. R.J. Sizemore et al. [22] and V. Shevchenko [23] state that such proteins as halorhodopsin, archaerhodopsin, and channel rhodopsin are classic optogenetic instruments (Figure 9). Halorhodopsin and archaerhodopsin are used to deactivate neurons and block a nerve impulse transfer. Under exposure to light halorhodopsin transfers negatively charged chlorine ions into a cell thus hyperpolarizing a neutron. Archaerhodopsin pumps protons (positive charges) out of a cell and it naturally also hyperpolarizes a neutron. Both halorhodopsin and archaerhodopsin are so called "pumps". Should there be an ion around that they need (and there is almost always one), then, having absorbed a quant of light, these proteins actively transfer an ion from one side of a membrane to another.

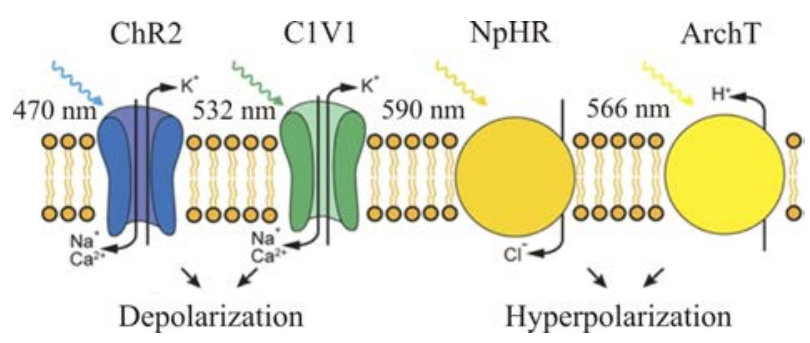

Figure 9. Principles of classic optogenetic instruments functioning: channel rhodopsin, halorhodopsin, and proton pump (archaerhodopsin)

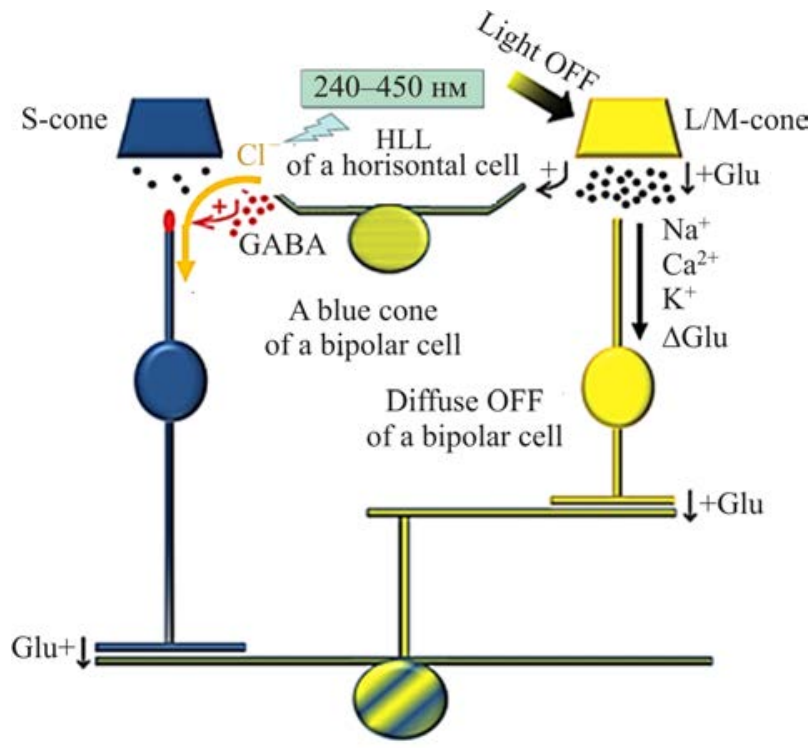

Figure 10. An overall scheme showing synapses placement between retina neurons [25] including a scheme for GABA and chlorine ions transfer as well as Glu and $\mathrm{Na}, \mathrm{Ca}$ и $\mathrm{K}$ ions transfer
Blue light with its wave length equal to $470 \mathrm{~nm}$ stimulates ChR2 protein for $\mathrm{Na}^{+}$and $\mathrm{Ca}^{+}$ions transfer. And we should note here that chlorine absorbs light with its wave length ranging within 250-450 $\mathrm{nm}$ [24]. Chlorine ions together with gamma-aminobutyric acid (GABA) are agents that inhibit neuron conduction. Glutamine acid (Glu) is the basic excitatory mediator (about $40 \%$ of all neurons). Gamma-Amino Butyric acid (GABA) is the basic inhibitory mediator (also about $40 \%$ of all neurons). A disorder in this balance (as a rule, a decrease in inhibition) exerts negative impacts on multiple nerve processes. Proper CNS functioning is provided due to a fine balance between Glu and GABA that are neuromediators in the eye retina (Figure 10).

When chlorine ions absorb excessive blue light dose, a decrease in chlorine ions concentration appears, and, consequently,

$$
2 \mathrm{Cl}^{-}-2 \mathrm{e}^{-} \rightarrow \mathrm{Cl}_{2} \uparrow,
$$

excitement-inhibition efficiency goes down and responses to an excitatory stimulus are delayed.

Ion exchangers function on neurons and astrocytes membranes; they maintain a necessary gradient in concentrations of chemicals between intracellular and intercellular spaces in physiological conditions (potassium ions $\mathrm{K}+$ and glutamate accumulate inside a cell, and calcium ions $\mathrm{Ca} 2+$, chlorine ions $\mathrm{Cl}-$, and sodium ions $\mathrm{Na}+$ accumulate outside it) [26, 27].

Astrocytes quantity is 20 times higher than neurons quantity. Astrocytes participate in hormone-induced restructure of synapses that perform endocrine functions [28].

Experts from University of California, San Diego School of Medicine, Johns Hopkins University School of Medicine, and Kennedy Krieger Institute revealed that certain neurons passed a function related to utilizing mitochondria (tiny intracellular energy stations) they no longer needed onto glia cells known as astrocytes. Experts focused their attention on axons of retina ganglionic cells or neurons that transferred visual information from the eye to the brain [29]. 
Intra-neuronal ion stricture is a significant factor that predetermines brain functioning. There is evidence that abnormal homeostasis of CL-([CL-] i) cellular concentration together with $\mathrm{Na}+$ и $\mathrm{Ca} 2+$ induces disorders in neurons excitability and nerve transmission thus making for occurrence of neurologic pathologies [30-33].

All neurodegenerative diseases have several common signs; they are a trend for progressing with slow functional degeneration; selective loss of specific neuron populations due to apoptosis; trans-synaptic degeneration (primary or secondary); common cell death mechanisms such as oxidative stress and glutamate toxicity ${ }^{7}$. «Garbage» accumulation inside cells can result in neurodegenerative processes [29]. Cells in the eye retina have dendritic fields and we can assume that pathology of synapse dendrites is one of the earliest glaucoma signs. Ganglionic cells with changed dendrites have a weaker response to visual stimuli and it confirms that there is a direct relation between dendrite degeneration and visual dysfunction, and that synapses are the most vulnerable component susceptible to a degenerative process that results in cell death ${ }^{7}$.

As opposed to electroencephalogram that shows brain cortex activity, visual induced cortical potentials (VICP) are an aggregated response from large neuron populations in the cortex that occurs due to a synchronic impulse flow induced by impacts exerted by an afferent irritant that comes to them. A difference in potentials that occurs between inter- and intracellular medium and is registered on a neutron membrane is determined by a difference in $\mathrm{Na}^{+}, \mathrm{K}^{+}$and $\mathrm{Cl}^{-}$ions concentration in extracellular medium and neuron protoplasm.

The author of the work ${ }^{4}$ noted that there were practically no changes in VICP (visual induced cortical potentials) amplitudes after operators having spent some time exposed to dynamic LED lighting; however, all the participants in the experiment has a W-like split in P100 peak as a response to stimuli with dif- ferent angle dimensions. There are no data in literature on similar changes in VICP morphology in healthy people spending some time in a pressurized object or being exposed to dynamic LED lighting, and it makes their assessment rather difficult. Probably, this result can be treated as evidence that dynamic LED lighting has border influence on functional state of the visual analyzer. In-depth study of the given phenomenon and clarifying its relation with functional activity of the retina and the brain will require a longer examination with much greater number of volunteers participating in it.

Mitochondria are organelles that perform a lot of significant functions including those related to providing cells with energy. Cells remove damaged mitochondria via a process that is called mitophagy. Mitophagy is a subelement in a process called autophagy; its aim is to deliver damaged organelles to liposomes for further degradation. Nevertheless, we have revealed that a great number of mitochondria leave neurons at a place called the optic nerve head in order to be degraded by lysosomes of the adjourning glia cells. This conclusion challenges an assumption that a cell necessarily degrades its own organelles.

The most important function performed by astrocytes is elimination of degrading mitochondria in ganglionic cells in order to maintain their viability and provide reliable and sustainable functioning when the eye is exposed to light loads. Absorption of ganglionic cells mitochondria was studied in detail in works by T.C. Burdett et al. [34], N.N. Osborne et al. [35], and S. La Fee [36]. This interaction between mitochondria and astrocytes is fundamentally important when it comes to impacts exerted on ganglionic cells by blue light.

The research performed by the author revealed that application of LED lighting based on «a blue crystal covered with yellow luminophor» LED technology could in future cause elevated risks of disorders in the visual analyzer functioning. In particular, the author

\footnotetext{
${ }^{7}$ L.A. Panyushkina. Clinical and morphological peculiarities of the visual tract in patients suffering from glaucoma and Alzheimer disease: a thesis for Candidate of Medical Sciences degree. Moscow, 2015, 106 p. (in Russian).
} 
states that «If layouts and dimensions of a pressurized object allow long-term dwelling of several crew members in one room, then people should be provided with glasses with spectral lenses. Such glasses allow not only facilitating adaptation of crew members to spectral and energetic properties of a lighting system but also reduce visual fatigue of an operator during work with VDU» ${ }^{4}$. The author also notes that «one should be cautions when using LED lighting with additional occurrence with a blue component in the irradiation spectrum of a lighting source. Long-term regular use of such lighting can result in morphofucntional changes in the visual analyzer (damage to the lens and eye retina); changes in mood (increased excitability, irritability, anger, and hostility); insomnia (difficulties in falling asleep, disorders in sleep structure and quality)» ${ }^{4}$.

This conclusion is especially important hence personnel living in northern mobile settlements and military personnel serving on ships and submarines have to spend much longer time under such conditions than a 12-day experiment.

It should be noted that the author used lighting sources manufactured by foreign companies; in our opinion, they will be unavailable for use in northern military bases should there be an increase in tensions between Russia and other countries. However, in Russia experts employed at Rospotrebnadzor's Russian Scientific Research Institute for Railway Hygiene and «ELTAN» LLC have developed theoretical grounds for a concept of «LED lighting sources with a biologically adequate spectrum» that is shown in Figure 11 [37].

The developed technology has been patented and it secures the priority Russia has in creating energy-efficient LED lighting sources with white light and biologically adequate spectra. To reduce effects produced by low-intensity "bluish" LED light, it is necessary to make a white light spectrum of a LED lighting sources close to a luminous lamp spectrum or, even better, to the sunlight spectrum with hygienically safe color temperature that is equal to $3,000 \mathrm{~K}$.

This white light spectrum has no disadvantages that are characteristic for any standard white LED (a blue crystal covered with yellow luminophor) such as a significant dose of blue light and a dip at $480 \mathrm{~nm}$ with an insignificant dose of red light. This spectrum is uninterrupted and its structure corresponds to that of the sunlight spectrum with safe color temperature that is equal to $3,000 \mathrm{~K}$.

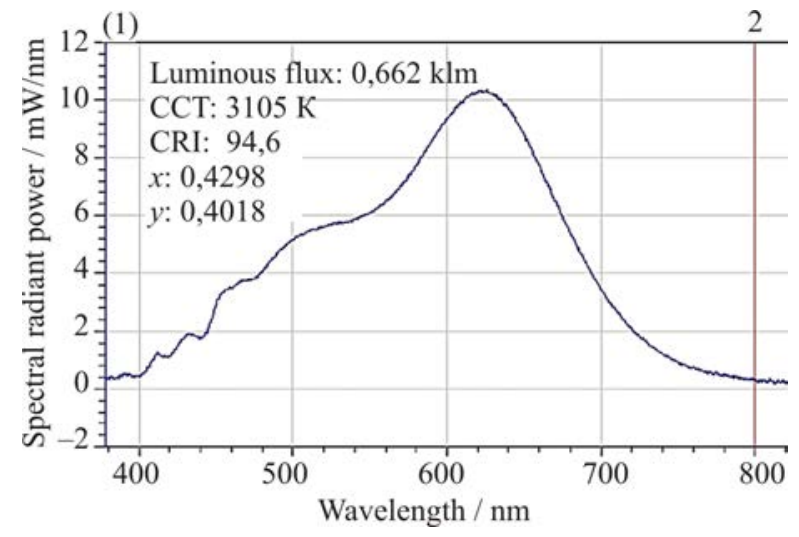

Figure 11. A light spectrum of updated retrofit lamps created by «ELTAN» LLC

We think that application of semi-conductor white light sources with biologically adequate spectra will provide:

- a decrease in negative influence exerted by light on the visual analyzed and the hormonal system;

- conditions for additional energy saving due to almost 2 times lower illuminance at workplaces with preserving the required labor productivity;

- stable light flow and required parameters of lighting system reliability.

\section{Conclusions:}

1. An original technology has been developed in Russia; it allows creating white LED lamps with biologically adequate light spectra. World priority of the technology is protected with a patent.

2. We recommend the authors of the GOST 23274-84 «Mobile buildings (inventory buildings). Electrical units. Overall technical conditions» to make amendments into unit 3.4.4 of the said document and state the following: «as a rule, lighting appliances with luminous lamps or white LED lighting sources with biologically adequate light spectra are to be used for electrical lighting of rooms inside mobile houses». 
3. A choice between LEDs with permanent or dynamic spectral and energetic properties depends on specific conditions and tasks to be solved: whether it is necessary to optimize balance between CNS excitation and inhibition or to achieve more apparent activating effects on most parameters of psychoemotional state.

4. It is necessary to accomplish wider research on new lighting sources in relation to tasks in the sphere of labor medicine, military and communal hygiene, common and occupational pathology in order to preserve population health and strengthen defense capacities of the country.

Funding. The research was not granted any financial support.

Conflict of interests. The authors declare there is no nay conflict of interests.

\section{References}

1. Skupov B. Tsilindricheskii unifitsirovannyi blok. Mobil'nyi dom dlya zhizni v ekstremal'nykh usloviyakh [A cylindrical unified block. A mobile house for living under extreme conditions]. Stroitel'nyi ekspert. Portal dlya spetsialistov arkhitekturno-stroitel'noi oblasti. Available at: https://ardexpert.ru/article/6227 (12.04.2019) (in Russian).

2. Zhilye vagon-doma. Dlya obespecheniya komfortnykh uslovii prozhivaniya i raboty na Krainem Severe [Mobile houses used for providing comfortable conditions for living and working in the Polar Regions]. CABA servis. Zavod mobil'nykh zdanii. Available at: https://www.savaservis.ru/catalog/vagondoma/zhilye/ (12.04.2019) (in Russian).

3. Leccese F., Vandelanotte V., Salvadori G., Rocca M. Blue Light Hazard and Risk Group Classification of 8 W LED Tubes, Replacing Fluorescent Tubes, through Optical Radiation Measurements. Sustainability, 2015, vol. 7, no. 10, pp. 13454-13468. DOI: 10.3390/su71013454

4. Vandelanotte V., Leccese F., Corucci T., Rocca M. Optical Radiation Measurements and Risk Group Determination of 8W LED Tubes for General Lighting. CIRIAF National Congress Environmental Footprint and Sustainable Development Perugia, Italy, 2015, pp. 1-11.

5. Bazyleva L.V., Bolekhan V.N., Ganapol'skii V.P. Svetodiody v kachestve osnovnogo osveshcheniya: problem i puti resheniya [LEDs as a basic lighting source: issues and ways to resolve them]. Materialy 3-go Aziatsko-Tikhookeanskogo kongressa po voennoi meditsine: sbornik tezisov konferentsii, Sankt-Peterburg, 2016, pp. 7-8 (in Russian).

6. Bolekhan V.N., Ganapol'skii V.P., Shchukina N.A., Bazyleva L.V. Kompleksnoe issledovanie vliyaniya svetodiodnykh istochnikov sveta na funktsional'noe sostoyanie organizma cheloveka [A complex examination of impacts exerted by LED lighting sources on functional state of a human body]. Meditsina i zdravookhranenie: materialy V Mezhdunarodnoi nauchnoi konferentsii. Kazan, Buk Publ., 2017, pp. 85-88 (in Russian).

7. Zak P.P., Ostrovskii M.A. Potential danger of light emitting diode illumination to the eye, in children and teenagers. Svetotekhnika, 2012, no. 3, pp. 4-6 (in Russian).

8. Smoleevskii A.E., Man'ko O.M., Bubeev Yu.A., Smirnova T.A. Psychophysiological effects of led lighting in conditions of the hermetic objects. Izvestiya Rossiiskoi voenno-meditsinskoi akademii, 2018, vol. 37, no. 2, pp. 124-127 (in Russian).

9. SB082-055 A Spectrally Dynamic Berth Light for Active Circadian Cycle Management. SBIR. STTR. America's seed fund, 2010. Available at: https://www.sbir.gov/sbirsearch/detail/166396 (12.04.2019).

10. Deinego V.N., Kaptsov V.A., Balashevich L.I., Svetlova O.V., Makarov F.N., Guseva M.G., Koshits I.N. Prevention of ocular diseases in children and teenager in classrooms with led light sources of the first generation. Rossiiskaya detskaya oftal'mologiya, 2016, no. 2, pp. 57-73 (in Russian).

11. SB082-055 A Spectrally Dynamic Berth Light for Active Circadian Cycle Management. SBIR. STTR. America 's seed fund, 2010. Available at: https://www.sbir.gov/sbirsearch/detail/131805 (12.04.2019).

12. Energy Focus, Inc. Receives \$1.6 Million to Develop LED Lighting for DARPA and NASA. LIGHTimes Online - LED Industry News. Available at: http://www.solidstatelighting.net/energy-focusinc-receives-1-6-million-to-develop-led-lighting-for-darpa-and-nasa/ (12.04.2019). 
13. Rao F., Chan A.H.S., Zhu X.-F. Effects of photopic and cirtopic illumination on steady state pupil size. Vision Research, 2017, vol. 137, pp. 24-28. DOI: 10.1016/j.visres.2017.02.010

14. Kurysheva N.I., Kiseleva T.N., Khodak N.A., Irtegova E.Yu. Issledovanie bioelektricheskoi aktivnosti i krovosnabzheniya setchatki pri glaukome RMZh [Research on bioelectrical activity and blood supply to the retina in patients with glaucoma]. RMZh. Klinicheskaya oftal'mologiya, 2012, vol. 13, no. 3, pp. 91-94 (in Russian).

15. Amirov A.N., Zainutdinov I.I., Zvereva O.G., Korobitsin A.N. Elektroretinograficheskie pokazateli sostoyaniya setchatki i zritel'nogo nerva u patsientov POUG primenyayushchikh Travatan [Electroretinogram parameters showing a state of the retina and optic nerve in patients with primary simple glaucoma who take Travatan]. Novosti glaukomy, 2016, vol. 37, no. 1, pp. 83-84 (in Russian).

16. Bach M., Brigell M.G., Hawlina M., Holder G.E., Johnson M.A., McCulloch D.L., Meigen T., Viswanathan S. ISCEV standard for clinical pattern electroretinography (PERG): 2012 update. Ophthalmol, 2013, no. 126, pp. 1-7. DOI: 10.1007/s10633-012-9353-y

17. Holder G.E. Pattern electroretinography (PERG) and an integrated approach to visual pathway diagnosis. Prog. Retin. Eye Res, 2001, vol. 20, no. 4, pp. 531-561. DOI: 10.1016/s1350-9462(00)00030-6

18. Egorov V.V., Smolyakova G.P., Borisova T.V., Gokhua O.I. Fizioterapiya v oftal'mologii: monografiya dlya vrachei-oftal'mologov i fizioterapevtov [Physiotherapy in ophthalmology: a monograph for ophthalmologists and physiotherapists]. Khabarovsk: Red.-izd. tsentr IPKSZ Publ., 2010, 335 p. (in Russian).

19. Skobareva Z.A., Teksheva L.M. Biologicheskie aspekty gigienicheskoi otsenki estestvennogo $\mathrm{i}$ iskusstvennogo osveshcheniya [Biological aspects in hygienic assessment of natural and artificial lighting]. Svetotekhnika, 2003, no. 4, pp. 7-13 (in Russian).

20. Zefirov A.L., Mukhamed'yarov M.A. Elektricheskie signaly vozbudimykh kletok [Electrical signals in excitable cells]. Kazan', Kazanskii gosudarstvennyi meditsinskii universitet Publ., 2008, pp. 119 (in Russian).

21. Chamma I., Chevy Q., Poncer J.C., Lévi S. Role of the neuronal K-Cl co-transporter KCC2 in inhibitory and excitatory neurotransmission. Front. Cell. Neurosci, vol. 21, no. 6, pp. 5. DOI: $10.3389 /$ fncel.2012.00005

22. Sizemore R.J., Seeger-Armbruster S., Hughes S.M., Parr-Brownlie L.C. Viral vector-based tools advance knowledge of basal ganglia anatomy and physiology. J. Neurophysiol, 2016, vol. 115, no. 4, pp. 2124-2146. DOI: 10.1152/jn.01131.2015

23. Shevchenko V. Svet, kamera ... nervnyi impul's! [Light, camera ... a nerve impulse!]. Biomolekula, 2017. Available at: https://biomolecula.ru/articles/svet-kamera-nervnyi-impuls\#source-5 (12.04.2019) (in Russian).

24. Fioletovyi [Violet]. Spravochnik khimika 21. Available at: http://chem21.info/info/193001/ (12.04.2019) (in Russian).

25. Puller C., Haverkamp S., Neitz M., Neitz J., Neuhauss S.C.F. Synaptic Elements for GABAergic Feed-Forward Signaling between HII Horizontal Cells and Blue Cone Bipolar Cells Are Enriched beneath Primate S-Cones. PLoS One, 2014, vol. 9, no. 2, pp. e88963. DOI: 10.1371/journal.pone.0088963

26. Makarov S.S., Dzhebrailova Y.N., Gracheva M.E., Grachev E.A., Kochetov A.G., Gubskii L.V. Mathematical modeling of group of neurons and astrocytes in ischemic stroke. Zhurnal nevrologii $i$ psikhiatrii im. S.S. Korsakova, 2012, vol. 112, no. 8 (2), pp. 59-62 (in Russian).

27. Drone M.A. A mathematical model of ion movements in grey matter during a stroke. Journal of Theoretical Biology, 2006, no. 240, pp. 599-615. DOI: 10.1016/j.jtbi.2005.10.023

28. Tereshina E.V. Obosnovanie metabolicheskoi sostavlyayushchei perfuzionnoi sredy dlya izolirovannogo mozga [Substantiating a metabolic component in perfusion medium for an isolated brain]. Rossiya-2045. Strategicheskoe obshchestvennoe dvizhenie, 2014. Available at: http://2045.ru/news/ 32991.html (13.04.2019) (in Russian).

29. Davis C.O., Kim K.-Y., Bushong E.A., Mills E.A., Boassa D., Shih T., Kinebuchi M., Phan S. [et al.]. Transcellular degradation of axonal mitochondria. PNAS, 2014, vol. 111, no. 26, pp. 9633-9638. DOI: $10.1073 /$ pnas.1404651111

30. Rahmati N., Hoebeek F.E., Peter S., De Zeeuw C.I. Chloride homeostasis in neurons with special emphasis on the olivocerebellar system: differential roles for transporters and channels. Front. Cell. Neurosci, 2018, no. 12, pp. 101. DOI: 10.3389/fncel.2018.00101 
31. Go M.A., Daria V.R. Light-neuron interactions: key to understanding the brain. Journal of Optics, 2017, vol. 19 , no. 2, pp. 023002. DOI: 10.1088/2040-8986/19/2/023002

32. Delpire E., Staley K.J. Novel determinants of the neuronal Cl- concentration. J. Physiol, 2014, vol. 1, no. 592 (19), pp. 4099-4114. DOI: 10.1113/jphysiol.2014.275529

33. Duebel J., Haverkamp S., Schleich W., Feng G., Augustine G.J., Kuner T., Euler T. Twophoton imaging reveals somatodendritic chloride gradient in retinal ON-type bipolar cells expressing the biosensor Clomeleon. Neuron, 2006, vol. 5, no. 49 (1), pp. 81-94. DOI: 10.1016/j.neuron.2005.10.035

34. Burdett T.C., Freeman M.R. Astrocytes eyeball axonal mitochondria. Retinal neurons transfer mitochondria to astrocytes for rapid turnover to meet energy demands. Science, 2014, vol. 25, no. 345 (6195), pp. 385-386. DOI: 10.1126/science. 1258295

35. Osborne N.N., Del Olmo-Aguado S. Maintenance of retinal ganglion cell mitochondrial functions as a neuroprotective strategy in glaucoma. Current Opinion in Pharmacolog, 2013, vol. 13, no. 1, pp. 16-22. DOI: 10.1016/j.coph.2012.09.002

36. LaFee S. Getting rid of old mitochondria: Some neurons turn to neighbors to help take out the trash. UC San Diego, 2014. Available at: https://www.technology.org/2014/06/17/getting-rid-oldmitochondria-neurons-turn-neighbors-help-take-trash/ (13.04.2019).

37. Kaptsov V.A., Deinego V.N., Ulasiuk V.N. Semiconductor sources of white light with biologically adequate radiation spectrum. Glaz, 2018, vol. 119, no. 1, pp. 25-33 (in Russian).

Kaptsov V.A., Deinego V.N. Irrational lighting as a health risk occurring in the arctic. Health Risk Analysis, 2020, no. 1, pp. 177-190. DOI: 10.21668/health.risk/2020.1.18.eng

Received: 29.10 .2019

Accepted: 09.02.2020

Published: 30.03.2020 